\title{
CHANGES IN POSTHARVEST PHYSIO-BIOCHEMICAL CHARACTERISTICS AND ANTIOXIDANT ENZYMES ACTIVITY OF CUT Alsteroemeria aurantiaca FLOWER AS AFFECTED BY CYCLOHEXIMIDE, COCONUT WATER AND 6-BENZYLADENINE
}

\author{
ALTERAÇÕES NAS CARACTERÍSTICAS FÍSICO-BIOQUÍMICAS PÓS-COLHEITA E \\ ATIVIDADES DE ENZIMAS ANTIOXIDANTES DA FLOR DE Alstroemeria aurantiaca \\ CORTADA COMO AFETADA PELA CICLOHEXIMIDA, ÁGUA DE COCO E 6- \\ BENZILADENINA
}

\author{
Saeedeh Alizadeh MATAK ${ }^{1}$; Davood HASHEMABADI ${ }^{{ }^{*}}$; Behzad KAVIANI $^{1}$ \\ Department of Horticulture, Rasht Branch, Islamic Azad University, Rasht, Iran. *davoodhashemabadi@yahoo.com
}

\begin{abstract}
Early leaf yellowing in cut alstroemeria (Alstroemeria aurantiaca) flowers before flower development and petal abscission is an important limiting postharvest quality and vase life factors. Early leaf senescence reduces postharvest longevity of cut flowers and promotes petal's wilting. A study was made to evaluate the response of cut alstroemeria flowers at varying concentrations of cycloheximide (CHI) $\left(50,100\right.$ and $\left.200 \mathrm{mg} \mathrm{l}^{-1}\right)$, coconut water $(5,10$ and 20\%) and 6-benzyladenine (BA) $\left(50,100\right.$ and $\left.200 \mathrm{mg} \mathrm{l}^{-1}\right)$. CHI, coconut water and BA extended the vase life at all concentrations compared to the control, but coconut water at $5 \%$ concentration (with 17.39 days) was the most effective treatment. Control cut flowers showed the least vase life (10.76 days). Ethylene production in cut flowers promoted flower senescence. All concentrations of CHI, coconut water and BA delayed ethylene production compared to the control. Treatment of cut flowers with coconut water at concentration of 5\% maintained the highest fresh weight of flowers and increased the content of water uptake. The chlorophyll degradation was significantly reduced by the application of CHI, coconut water and BA. The maximum content of membrane's lipid peroxidation and antioxidant enzymes activity (super oxide dismutase and peroxidase) was obtained in control cut flowers. Thus, $5 \%$ fresh coconut water has the potential to be applied as vase solution (preservative medium) due to prolongs of cut alstroemeria flowers.
\end{abstract}

KEYWORDS: Longevity. Ornamental plants. Petal senescence. Plant growth regulators. Vase life.

\section{INTRODUCTION}

Alstroemeria (Alstroemeria aurantiaca), commonly called the Peruvian Lily or Lily of the Incas or Parrot Lily is a South American genus of about 60 species of flowering plants, mainly from the cool, mountainous regions in the Andes. Alstroemeria from Alstroemeriaceae family is widely used as a cut flower. Alstroemeria is one of the most beautiful genus of this family. This species is sensitive to ethylene and has relatively short postharvest life. Ethylene has an important role in senescence, rolling, wilting and abscission of the petals (KIM, 2005). Nowadays, many chemical and biological constitutes are used for extending the vase life of cut flowers. Use of preserving substances in vase solution is a widely used method for increasing the vase life.

Coconut water is a rich resource of organic compounds especially plant growth regulators (PGRs) like auxins, cytokinins and gibberellins. Coconut water has been used to extend the postharvest longevity of some cut flowers (NAIR et al., 2000; AGAMPODI; JAYAWARDENA, 2007). Cytokinins promote the transport, accumulation and retention of metabolites in tissues and organs and protect membranes against degradation (BECKMAN; INGRAM, 1994). It has been shown that cytokinins extend the vase life of several cut flowers (NOWAK; RUDNICHI, 1990; HAN, 2001; HUANG; CHEN, 2002; HATAMZADEH et al., 2012). Senescence of many flowers is coordinated by a rise in ethylene biosynthesis (HASSANPOUR; KARIMI, 2010). Pulse treatment with cytokinins like BA delayed ethylene production and extended the vase life of cut Alstroemeria flowers and some other flowers (MUTUI et al., 2001). Also, BA could delay the change in fresh weight, respiration rate and water uptake (KITTISIRIPAT; TECHAWONGSTIEN, 2007; HATAMZADEH et al., 2012). The effect of PGRs, such as cytokinins on delaying chlorophyll degradation and leaf yellowing has been shown (HAN, 1997; 2001). Effect of cytokinins on the extension of vase life depended upon flower type, season of harvest and cultivar (PAULL; CHANTRACHIT, 2001). 
One of the most important signs of petal senescence is protein degradation and remobilization (WAGSTAFF et al., 2002). Treatment of cut flowers with protein biosynthesis inhibitors increases their postharvest life. The extension of vase life in cut flowers can be achieved by the use of specific protein synthesis inhibitors. Cycloheximide $\left(\mathrm{C}_{15} \mathrm{H}_{23} \mathrm{NO}_{4}\right)$ (CHI), is a protein synthesis inhibitor at translational level (TOBITA; SHONO, 2001). CHI maintains the protein content and delays the visible symptoms of petal senescence (SULTAN; FAROOQ, 1996). It has been demonstrated to delay senescence in several ornamental plants (GULZAR et al., 2005; SHAHRI; TAHIR, 2010; GUL et al., 2012; GUL; TAHIR, 2013). CHI inhibits the flower opening and also delays senescence (SULTAN et al., 2002; GULZAR et al., 2005; ZHOU et al., 2005). The role of CHI in delaying the cut flowers senescence has been shown by several researchers (VAN DOORN et al., 1995; GULZAR et al., 2005; SHAHRI; TAHIR, 2011; ISLAM et al., 2011).

This study on Alstroemeria aurantiaca was established to evaluate the role of coconut water, $\mathrm{BA}$ and $\mathrm{CHI}$ on extending the vase life of cut flowers.

\section{MATERIAL AND METHODS}

\section{Experimental Conditions and Plant Material}

Alstroemeria (Alstroemeria aurantiaca) cut flowers harvested at commercial stage were bought from Tehran city, Iran on May 2015 and immediately transferred to the postharvest laboratory for experiments. The experiments were carried out in postharvest laboratory, Islamic Azad University, Rasht, Iran. The flowers were cut to a uniform length of $52 \mathrm{~cm}$.

\section{Procedure and Experimental Design}

This study was performed based on completely randomized design with three factors containing cycloheximide (CHI) sprayed at three levels $\left(50,100\right.$ and $\left.200 \mathrm{mg} \mathrm{l}^{-1}\right)$, fresh coconut water (5, 10 and 20\%) and 6-benzyladenine (BA) (50, 100 and $200 \mathrm{mg} \mathrm{l}^{-1}$ ), as well control. This experiment consisted of 10 treatments, 3 replications and 5 cut flowers in each plot. Cut flowers were kept in plastic pots containing 3\% sucrose as preservative solution. The laboratory maintained a temperature of $20 \pm 2{ }^{\circ} \mathrm{C}$, in cool white fluorescent light $(12$ $\mu$ mole $\left.\mathrm{m}^{-2} \mathrm{~s}^{-1}\right), 12 \mathrm{~h}$ a day and RH of $60-70 \%$. Data were recorded on vase life (postharvest longevity), the content of ethylene production, water uptake, the amount of fresh weight, total chlorophyll content in leaves, petal's carotenoid content, lipid peroxidation (MDA) and activity of superoxide dismutase (SOD) and peroxidase (POD) enzymes.

\section{Assessment of Characteristics}

Vase life. The average vase life of the cut flowers was calculated from the day of transfer of flowers to the preservative solution and was assessed to be terminated when $50 \%$ of flowers had senesced, which was characterized by loss of turgor followed by petal wilting. Petal senescence was marked by the loss of turgor in the petal tissues followed by complete wilting.

Ethylene production. To measure the amount of released ethylene by cut flowers, after $\mathrm{CHI}$, coconut water and BA treatment, a cut flower was selected from each plot at second day and placed in a jar. The mouth of the jars was sealed to prevent air movement. After $12 \mathrm{~h}$, the gas from inside the jar was sampled and sent to the analysis laboratory. Ethylene production was measured by GC-AIT 8, manufactured by Schimadzu Corporation, Japan.

Water uptake. Water uptake was calculated by considering initial volume of vase solution $(600 \mathrm{ml})$ and the rate of evaporation in room and reduction of volume of vase solution using following equation:

Water uptake $\left(\mathrm{ml} \mathrm{g}^{-1}\right.$ F.W. $)=600-($ mean evaporation of room + remained solution at the end of vase life) $\div$ the average of fresh weight of five cut flowers

Increase of fresh weight. Regarding the final weight of flower in the last day, recuts weight, loss of weight and weight of the first day, the increase of fresh weight was calculated according to the following equation:

Increase of fresh weight $=$ (weight of losses + weight of recuts + final weight at last day of the control life flowers) - initial weight

Chlorophyll content. At the end of cut flower life, a flower was removed from each plot to measure leaf chlorophyll content. The total chlorophyll content was measured using MAZUMDAR; MAJUMDAR (2003) method. Photosynthetic pigments were extracted first. One gram of leaf was ground in liquid nitrogen using a mortar and pestle. The $10 \mathrm{ml}$ of $80 \%$ acetone was added to a $15 \mathrm{ml}$ Falcon tube, and mixed in dark for $15 \mathrm{~min}$. The mixture was filtered through two 
Whatman filter papers. The absorbance of chlorophyll was measured with three replications at two wavelengths, 642.5 and $660 \mathrm{~nm}$ using spectrophotometry. Total chlorophyll concentration was calculated as follows:

Total chlorophyll $(\mathrm{mg} / \mathrm{g})=7.12\left(\mathrm{~A}_{660}\right)+16.8$ $\left(\mathrm{A}_{642.5}\right)$

Where; "A" is light absorbance at wavelengths of 660 and $642.5 \mathrm{~nm}$.

Carotenoids content. To measure carotenoids, a cut flower was removed from each plot at the end of vase life of control and its carotenoid was measured by MAZUMDAR; MAJUMDAR (2003) method. The $0.5 \mathrm{~g}$ frozen petals were macerated in a mortar with a pestle in 1 $\mathrm{ml}$ of $85 \%$ methanol $(85 \%$ methanol $+15 \%$ acetic acid) and were kept in a refrigerator for $24 \mathrm{~h}$. After this time, the macerate was centrifuged at $10000 \times$ $\mathrm{g}$, at the temperature of $4^{\circ} \mathrm{C}$ for $10 \mathrm{~min}$ and the supernatant was used to determine its carotenoids content. To determine carotenoids content of petals, the supernatant was filtered and $50 \mu \mathrm{l}$ of it was injected to the HPLC, Waters 1525 model with column of C18, $250 \mathrm{~mm}$ in length and $4.6 \mathrm{~nm}$ in particles diameter.

Lipid peroxidation (MDA) content. A cut flower was removed at the end of vase life of the control flower and its petals were used for measurement of MDA. Petal samples $(0.25 \mathrm{~g})$ were homogenized in $1 \mathrm{ml}$ of $0.1 \%$ trichloroacetic acid (TCA). The homogenate was centrifuged at 14000 $\times \mathrm{g}$ for $15 \mathrm{~min}$, and then $500 \mu \mathrm{l}$ of supernatant was added to $500 \mu \mathrm{l}$ of $0.5 \%$ thiobarbituric acid (TBA) in $20 \%$ TCA. The mixture was heated at $95^{\circ} \mathrm{C}$ for 30 min and then cooled in an ice bath. After centrifugation at $10000 \times \mathrm{g}$ for $10 \mathrm{~min}$, the absorbance of the supernatant was calculated at 532 nm. The MDA content was measured when the extinction coefficient of the sample was $155 \mathrm{mM}$ $\mathrm{cm}^{-1}$.

Superoxide dismutase (SOD) activity. A cut flower was removed at the end of vase life of the control flower and its petals were used for measurement of POD. Measurement of SOD was done using spectrophotometry by GIANNOPOLITIS; RIES (1997) method. Each enzymatic extract used for measuring SOD activity was prepared by freezing $0.5 \mathrm{~g}$ of tissue in liquid nitrogen and then grinding the tissue in $1 \mathrm{ml}$ of extraction buffer $[50 \mathrm{mM}$ phosphate buffer, $\mathrm{pH} 7$ and $0.1 \mathrm{~g}$ PVPP $(\mathrm{w} / \mathrm{v})]$. The resulted homogenate was centrifuged for $15 \mathrm{~min}$ at $14000 \times \mathrm{g}$, and the supernatant was used to determine enzymatic activity.

Peroxidase (POD) activity. A cut flower was removed at the end of vase life of the control flower and its petals were used for measurement of POD. Each extract used for measuring POD activity was prepared by freezing of the $0.5 \mathrm{~g}$ of petal tissue in liquid nitrogen and then grinding the tissue in 10 $\mathrm{ml}$ of extraction buffer $[50 \mathrm{mM}$ phosphate buffer, $\mathrm{pH} 7$ containing $0.5 \mathrm{mM}$ EDTA and 2\% PVPP $(\mathrm{w} / \mathrm{v})]$. The resulted homogenate was centrifuged for 20 min at $15000 \times \mathrm{g}$, and the supernatant was used to determine enzymatic activity. POD activity was assayed by spectrophotometric measurement of guaiacol formation in $1 \mathrm{ml}$ of a reaction mixture consisting of $450 \mu \mathrm{l}$ of $25 \mathrm{mM}$ guaiacol, $450 \mu \mathrm{l}$ of $225 \mathrm{mM} \mathrm{H} \mathrm{H}_{2} \mathrm{O}_{2}$ and $100 \mu \mathrm{l}$ of crude enzyme. The activity is expressed as $\mathrm{mM}$ per $\mathrm{mg}$ of fresh weight.

\section{Statistical Analysis}

Data analysis was performed using SAS software and mean comparison was considered according to LSD test. EXCEL software was used to draw graphs.

\section{RESULTS}

\section{Vase Life}

The average vase life of cut $A$. aurantiaca flowers harvested at mature bud stage was about 10 days in water or sucrose. Petal senescence and yellowing leaf were characterized by loss of turgor initiating and degradation of some pigments. All treatments showed extended vase life over the control, as this difference was significant $(\mathrm{p}<0.01$, analysis of variance and LSD test) (Table 1). The medium vase life of cut flowers treated with various concentrations of $\mathrm{CHI}$, coconut water and BA was about 15 days. Treatment of cut flowers with 5\% coconut water resulted in the longest vase life (17.39 days) (Table 2). This postharvest longevity is about 7 days more in comparison to untreated control cut flowers. Coconut water (containing cytokinins) and BA are the anti-ethylene compound that during pulse treatment increased vase life of alstroemeria approximately 7 days more than that of the control cut flowers. Continuous $\mathrm{CHI}$ treatment on cut flowers increased the vase life of cut flowers more than the control but less than coconut water and BA (Table 2).

\section{Ethylene Production}

The results showed that the ethylene production (2.26 $\mathrm{nl} \mathrm{l}^{-1} \mathrm{~h}^{-1} \mathrm{~g}^{-1}$ F.W.) was maximum in untreated flowers. The ethylene production 
increased as the concentrations of coconut water, BA and CHI increased (Table 2). In the other word, there was a negative correlation between increasing ethylene production and decreasing the treatments concentration (Table 2). Significant differences $(\mathrm{p}<0.01)$ were obtained for ethylene production (Table 1). The highest means of ethylene production inhibition $\left(0.13 \mathrm{nl} \mathrm{l}^{-1} \mathrm{~h}^{-1} \mathrm{~g}^{-1}\right.$ F.W. $)$ was found with $20 \%$ coconut water.

\section{Water Uptake and Fresh Weight}

Water uptake rate increased in all treatments tested in comparison with the control. Thus, minimum water uptake $\left(0.703 \mathrm{mg} \mathrm{g}^{-1}\right.$ F.W. $)$ was done by untreated cut flowers (Table 2). The cut flowers treated with $5 \%$ coconut water showed the maximum water uptake (1.696 $\mathrm{mg} \mathrm{g}^{-1}$ F.W.). Cut flowers treated with $10 \%$ coconut water, $50 \mathrm{mg} \mathrm{l}^{-1}$ $\mathrm{BA}$ and $100 \mathrm{mg} \mathrm{l}^{-1} \mathrm{BA}$, respectively with 1.673 , 1.616 and $1.570 \mathrm{mg} \mathrm{g}^{-1}$ F.W. were shown suitable water uptake (Table 2). Treatment of cut flowers with $5 \%$ coconut water resulted in the highest increase in fresh weight $(5.68 \mathrm{~g})$. The highest decrease in fresh weight $(1.56 \mathrm{~g})$ was recorded in untreated cut flowers (Table 2). The fresh weight increased as the concentration of $\mathrm{CHI}$ increased (Table 2).

\section{Chlorophyll and Petal's Carotenoids Content}

The application of coconut water, BA and $\mathrm{CHI}$ at all concentrations delayed the chlorophyll and carotenoids degradation in comparison to control. Results obtained by spectrophotometer showed that the cut flowers treated with $50 \mathrm{mg} \mathrm{l}^{-1}$ $\mathrm{CHI}$ and $5 \%$ coconut water significantly had more leaf chlorophyll content $\left(8.410\right.$ and $7.993 \mathrm{mg} \mathrm{g}^{-1}$ F.W., respectively) in comparison to the other treatments and untreated control. Means comparison of the data revealed that the differences between treatments were not significant and all of those were put at the same group. But, this difference in the content of petal's carotenoids between cut flowers treated and untreated was significant (Table 1 and 2).

\section{Membrane's Lipid Peroxidation (MDA) \\ Information obtained from means comparison of the data revealed that the control cut flowers produced more MDA than the other cut flowers treated with coconut water, BA and $\mathrm{CHI}$ at all concentrations (Table 2). Thus, the highest content of MDA (20.09 nmol g ${ }^{-1}$ F.W.) was obtained from the control cut flowers. On the other hand, the lowest content of MDA ( $9.21 \mathrm{nmol} \mathrm{g}^{-1}$ F.W.) was obtained from the cut flowers treated with $100 \mathrm{mg} \mathrm{l}^{-}$ ${ }^{1}$ CHI.}

\section{Superoxide Dismutase (SOD) and Peroxidase (POD) Enzymes Activity}

The effect of coconut water, BA and CHI on SOD and POD enzymes activity was significant $(\mathrm{p}<0.01)$ (Table 1). Activity of the SOD and POD enzymes was changed as coconut water, BA and CHI concentrations altered. Maximum and minimum activity of SOD enzyme was related to various concentrations of $\mathrm{CHI}$. Therefore, the maximum activity of the SOD enzyme $(40.80 \mathrm{nmol}$ $\mathrm{g}^{-1}$ F.W.) was observed in untreated cut flowers and flowers treated with 100 and $200 \mathrm{mg} \mathrm{l}^{-1} \mathrm{CHI}$ (Table 2). Also, the minimum one was observed in cut flowers treated with $50 \mathrm{mg} \mathrm{l}^{-1}$ CHI. Maximum activity of the POD enzyme was found in untreated cut flowers (control). Activity of this enzyme in cut flowers treated with $20 \%$ coconut water was higher than that of other cut flowers except for the control (Table 2). The minimum activity of POD enzyme was observed in cut flowers treated with 5\% coconut water. Various concentrations of coconut water induced the most alteration at POD enzyme activity (Table 2). 
Table 1. Analysis of variance (ANOVA) of the effect of different concentrations of coconut water, BA and cycloheximide on measured characteristics in cut alstroemeria (Alstroemeria aurantiaca) flowers.

\begin{tabular}{cccccccccccc}
\hline Source of Variance & Df & Vase life & Water absorption & Fresh weight & Total chlorophyll & Carotenoid Ethylene MDA & SOD & POD \\
\hline Treatments & 9 & $10.96^{* *}$ & $0.31^{* *}$ & $4.36^{*}$ & $9.43^{* *}$ & $0.41^{* *}$ & $2.47^{* *}$ & $30.39^{* *}$ & $40.51^{* *}$ & $30.95^{* *}$ \\
Error & 20 & 2.78 & 0.07 & 1.45 & 0.009 & 0.008 & 0.12 & 1.74 & 4.21 & 0.002 \\
CV $(\%)$ & & 11.34 & 20.92 & 37.99 & 1.63 & 1.94 & 8.8 & 9.62 & 8.77 & 1.27 \\
\hline
\end{tabular}

: Significant at $\alpha=1 \%,{ }^{*}:$ Significant at $\alpha=5 \%,{ }^{\text {ns }}=$ Not significant

Table 2. Means comparison of the effect of different concentrations of coconut water, BA and cycloheximide on measured characteristics in cut alstroemeria (Alstroemeria aurantiaca) flowers.

\begin{tabular}{|c|c|c|c|c|c|c|c|c|c|}
\hline Treatment & $\begin{array}{c}\text { Vase life } \\
\text { (day) }\end{array}$ & $\begin{array}{l}\text { Water uptake } \\
\left(\mathrm{ml} \mathrm{g}^{-1} \mathrm{~F} . \mathrm{W}\right)\end{array}$ & $\begin{array}{c}\text { Fresh } \\
\text { weight } \\
(\mathrm{g})\end{array}$ & $\begin{array}{c}\text { Total } \\
\text { chlorophyll } \\
\left(\mathrm{mg} \mathrm{g}^{-1} \text { F.W.) }\right.\end{array}$ & $\begin{array}{l}\text { Carotenoid } \\
\left(\mu \mathrm{g} \mathrm{g}^{-1}\right. \\
\text { D.W. })\end{array}$ & $\begin{array}{c}\text { Ethylene } \\
\left(\mathrm{nl} \mathrm{l}^{-1} \mathrm{~h}^{-1} \mathrm{~g}^{-1}\right. \\
\text { F.W. })\end{array}$ & $\begin{array}{c}\text { MDA } \\
\left(\mathrm{nmol} \mathrm{g}^{-1}\right. \\
\text { F.W. })\end{array}$ & $\begin{array}{l}\text { SOD } \\
\left(\mathrm{IU} \mathrm{g}{ }^{-1}\right. \\
\text { F.W.) }\end{array}$ & $\begin{array}{c}\text { POD } \\
\left(\mathrm{nmol} \mathrm{g} \mathrm{F.W.}^{-1}\right. \\
\left.\min ^{-1}\right)\end{array}$ \\
\hline$\overline{\mathrm{C}_{0}}$ & $10.76^{\mathrm{d}}$ & $0.70^{\mathrm{d}}$ & $1.56^{\mathrm{d}}$ & $2.56^{\mathrm{h}}$ & $4.46^{b}$ & $2.26^{\mathrm{a}}$ & $20.09^{\mathrm{a}}$ & $28.02^{\mathrm{a}}$ & $10.32^{\mathrm{a}}$ \\
\hline $\mathrm{C}_{1}$ & $12.91^{\mathrm{cd}}$ & $1.02^{\mathrm{cd}}$ & $1.91^{\mathrm{cd}}$ & $8.41^{\mathrm{a}}$ & $4.86^{\mathrm{a}}$ & $1.65^{b}$ & $11.03^{\mathrm{de}}$ & $19.83^{\mathrm{c}}$ & $4.29^{c}$ \\
\hline $\mathrm{C}_{2}$ & $13.88^{b c}$ & $1.09^{\mathrm{cd}}$ & $2.39^{\mathrm{bcd}}$ & $5.96^{\mathrm{e}}$ & $4.82^{\mathrm{a}}$ & $1.14^{\mathrm{bc}}$ & $9.21^{\mathrm{e}}$ & $28.94^{\mathrm{a}}$ & $3.28^{\mathrm{e}}$ \\
\hline $\mathrm{C}_{3}$ & $13.71^{\mathrm{bc}}$ & $1.21^{\mathrm{bc}}$ & $2.85^{\mathrm{bcd}}$ & $4.89^{\mathrm{f}}$ & $4.82^{\mathrm{a}}$ & $0.76^{\mathrm{cd}}$ & $14.26^{\mathrm{bc}}$ & $28.24^{\mathrm{a}}$ & $2.82^{\mathrm{f}}$ \\
\hline $\mathrm{B}_{1}$ & $15.71^{\mathrm{abc}}$ & $1.61^{\mathrm{ab}}$ & $3.40^{\mathrm{bcd}}$ & $5.85^{\mathrm{e}}$ & $4.87^{\mathrm{a}}$ & $1.50^{\mathrm{b}}$ & $13.16^{\mathrm{cd}}$ & $22.24^{\mathrm{bc}}$ & $3.39^{\mathrm{d}}$ \\
\hline $\mathrm{B}_{2}$ & $15.74^{\mathrm{abc}}$ & $1.57^{\mathrm{ab}}$ & $2.66^{\text {bcd }}$ & $5.90^{\mathrm{e}}$ & $4.76^{\mathrm{a}}$ & $1.18^{\mathrm{bc}}$ & $15.49^{b}$ & $21.32^{\mathrm{bc}}$ & $1.64^{\mathrm{g}}$ \\
\hline $\mathrm{B}_{3}$ & $15.87^{\mathrm{ab}}$ & $1.34^{\mathrm{abc}}$ & $3.23^{\mathrm{bcd}}$ & $6.60^{\mathrm{d}}$ & $4.76^{\mathrm{a}}$ & $0.48^{\mathrm{d}}$ & $16.01^{\mathrm{b}}$ & $24.12^{\mathrm{b}}$ & $1.47^{\mathrm{h}}$ \\
\hline $\mathrm{S}_{1}$ & $17.39^{\mathrm{a}}$ & $1.69^{\mathrm{a}}$ & $5.68^{\mathrm{a}}$ & $7.99^{\mathrm{b}}$ & $4.83^{\mathrm{a}}$ & $1.00^{\mathrm{bc}}$ & $14.88^{\mathrm{bc}}$ & $21.00^{\mathrm{bc}}$ & $1.13^{\mathrm{i}}$ \\
\hline $\mathrm{S}_{2}$ & $15.88^{\mathrm{ab}}$ & $1.67^{\mathrm{a}}$ & $4.26^{\mathrm{ab}}$ & $6.82^{c}$ & $4.79^{\mathrm{a}}$ & $0.49^{\mathrm{d}}$ & $12.75^{\mathrm{cd}}$ & $20.04^{\mathrm{c}}$ & $3.89^{\mathrm{d}}$ \\
\hline $\mathrm{S}_{3}$ & $15.35^{\mathrm{abc}}$ & $1.25^{\mathrm{abc}}$ & $3.80^{\mathrm{abc}}$ & $3.93^{\mathrm{g}}$ & $4.84^{\mathrm{a}}$ & $0.13^{\mathrm{e}}$ & $10.29^{\mathrm{e}}$ & $20.23^{c}$ & $9.59^{b}$ \\
\hline
\end{tabular}

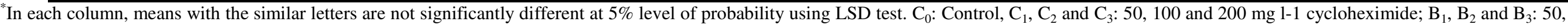
100 and $200 \mathrm{mg}$ l-1 BA; $\mathrm{S}_{1}, \mathrm{~S}_{2}$ and $\mathrm{S}_{3}: 5,10$ and $20 \%$ coconut water, respectively. 


\section{DISCUSSION}

The results of current experiments showed that the treatment of cut A. aurantiaca flowers at all levels of coconut water, BA and CHI enhanced vase life in comparison with the control. However, at lower concentration of coconut water (5\%), cut flowers maintained their postharvest quality more than that of other treatments. All concentrations of coconut water were more effective than all concentrations of $\mathrm{CHI}$ and $\mathrm{BA}$. It has been demonstrated that coconut water contains PGRs like auxins, cytokinins and gibberellins (MAMARIL et al., 1986). AGAMPODI; JAYAWARDENA (2007) showed that the $50 \%$ coconut water extended the vase life of cut Anthurium flowers up to 21 days. Similar finding was reported on cut Gerbera flowers (NAIR et al., 2000).

Positive effect of cytokinins on prolonging the vase life of cut Alstroemeria flowers has previously been demonstrated (MUTUI et al., 2001; CHAMANI et al., 2006; FERRANTE et al., 2009; HATAMZADEH et al., 2012). External treatment of cytokinins delays cut flowers senescence (LOUBAUD; VAN DOORN, 2004). Similar finding was reported by some researchers in alstroemeria and other ornamental plants (HICHLENTON, 1991; VAN DOORN, 1997; NAIR et al., 2000; GULZAR et al., 2005). Results obtained by HATAMZADEH et al., (2012) showed that the pulse treatment of cut Alstroemeria flowers with $10 \mu \mathrm{M}$ TDZ (a cytokinin-like PGR) delayed petal abscission (3.3 days) and leaf yellowing (25.7 days) compared to the untreated flowers. External application of BA had been effective on delaying senescence of various cut flowers by arresting degradation of protein and chlorophyll (MUTUI et al., 2001). BA effectively increased the vase life of cut Anthurium flowers (PAULL; CHANTRACHIT, 2001; FERRANTE et al., 2009). Cytokinins KIN and BAP markedly delayed senescence and prolonged longevity and flower quality in CHI sprayed cut Hemerocallis fulva flowers (GULZAR et al., 2005). Cytokinins treatment delay leaf senescence and improve the keeping quality of many cut flowers (EMONGOR et al., 2000; MUTUI et al., 2001). HASSANPOUR; KARIMI (2010) showed that BA extended the vase life of cut Eustoma grandiflora flowers at all concentrations.

Alstroemeria is very sensitive to ethylene and ethylene produced in the final growing stage of this cut flower decreases its vase life with falling sepals and petals (WAGSTAFF et al., 2002; CHANASUT et al., 2003). Ethylene production of cut flowers increased flower senescence. BA delayed ethylene production of Eustoma grandiflora compared to the control (HASSANPOUR; KARIMI, 2010). Cytokinins like BA reduce the sensitivity of tissues to endogenous ethylene thus, delay senescence. Findings show that cytokinins involve in ethylene signaling (SMITH et al., 1999). Ethylene treatment induces cytokinins accumulation and delays flower senescence (CHANG et al., 2003). Autocatalytic ethylene production was inhibited by BA (HUANG; CHEN, 2002). Ethylene causes premature wilting, color fading, abscission of petals and leaf yellowing (CELIKEL et al., 2002). Cytokinins may play a role in modulating the effects of ethylene in cut flowers (SANKHLA et al., 2005b). Ethylene treatment induced cytokinin accumulation and delayed flower senescence (CHANG et al., 2003).

Some studies revealed that $\mathrm{CHI}$ inhibits flower opening and delays senescence (ZHUO et al., 2005; ISLAM et al., 2011; GUL; TAHIR, 2013). CHI improves water balance in cut flowers that resulted in delaying the senescence (ISLAM et al., 2011). Gulzar et al. (2005) and Islam et al. (2011) showed that spraying isolated cut Hemerocallis fulva flowers with $0.5 \mathrm{mM} \mathrm{CHI} \mathrm{before} \mathrm{transfer} \mathrm{to}$ holding solution increased their longevity two days more than that of control. Similar finding was observed by Gul et al. (2012) on cut Nerine sarniensis flowers. These researchers revealed that the vase life was decreased and senescence was accelerated when the cut flowers pretreated with 0.1-0.5 mM CHI before holding in vase solution. Also, $\mathrm{CHI}$ at 0.01 and $0.05 \mathrm{mM}$ concentrations delayed senescence and increased vase life in cut Ranunculus asiaticus L. and Narcissus tazetta flowers (SHAHRI; TAHIR, 2011; GUL; TAHIR, 2013). These workers demonstrated that CHI maintains a high protein content in the petal tissue by inhibiting the synthesis of specific proteases responsible for protein degradation. The effects of $\mathrm{CHI}$ indicate a program at the cellular level.

Extending the vase life of cut flowers depends on a continuous and adequate supply of water. Failure of water supply, results in rapid wilting of stem, petal, and leaves (HASSANPOUR; KARIMI, 2010). Maintenance of water balance in cut flowers is an important factor to increase the vase life of cut flowers. The rate of water absorption by cut flowers depends on the hydraulic conductivity of stem and difference between water potential of cut flowers and preservative solution (VAN MEETEREN; VAN GELDER, 1999). DA SILVA (2003) reported that the water balance is the most important factor to determine the quality and vase life of cut flowers. Balance between water 
absorption and respiration is need to maintain the quality and vase life of cut flowers. Our study showed that all levels of coconut water, BA and $\mathrm{CHI}$ increased water uptake in comparison with the control. It is clear that the presence of microorganisms in vase solutions can cause physical plugging of cut stems, release toxic metabolites and result in programmed cell death (ALVAREZ, 2000). Water balance is a major factor that determines quality and longevity of cut flowers. It is influenced by water uptake and transpiration, being balance between these two processes (DA SILVA, 2003). Low water uptake is often due to occlusions located mainly in the basal stem end and microbes are common cause of stem end blockage (VAN DOORN, 1997). This researcher indicated that vascular blockage causes a water deficit and thereby shortens the vase life. Study of ISLAM et al. (2011) on Hemerocallis fulva showed that water uptake was increased in cut flowers held in vase solution containing 0.01-0.05 mM CHI, however a decrease in water uptake was seen with the increase in CHI concentration to $0.5 \mathrm{mM}$. Similar finding was observed by Van Doorn et al. (1995) on Iris. Hassanpour; Karimi (2010) showed that the higher BA concentration $\left(75 \mathrm{mg} \mathrm{l}^{-1}\right)$ reduced water uptake and the rate of senescence increased. But, BA at 25 and $50 \mathrm{mg} \mathrm{l}^{-1}$ increased water uptake, therefore retarding weight loss. Our finding is consistent with this study. Beginning of the senescence phase in cut flowers is characterized by a decrease in fresh weight and water uptake (BURGE et al., 1996; ADACHI et al., 2000; ICHIMURA; GOTO, 2002).

Enhancement of vase life of cut flowers has a positive relation with the delay in loss of fresh weight (ZULIANA et al., 2008; GUL; TAHIR, 2013). Most cut flowers showed the signs of water shortages when they were placed into the water. This water stress is a result of vascular obstruction and water conductivity decrease in the stem or an increase in the amount of evapotranspiration and transpiration. Extending the vase life of cut flowers depends on adequate supply of water and any problem in water uptake can result in rapid wilting of petal and leaf and decrease in fresh weight which accounts as the onset of senescence (ICHIMURA et al., 2000). Our study showed that all treatments especially coconut water increased fresh weight of cut flowers in comparison with control. These treatments increase water uptake and decrease respiration. Study of Hatamzadeh et al. (2012) showed that pulse treatment of Alstroemeria cut flowers with $10 \mu \mathrm{M}$ TDZ increased fresh weight. Shahri; Tahir (2011) and Gul; Tahir (2013) revealed that pretreatment of cut Ranunculus asiaticus L. and
Narcissus tazetta flowers with Chi at 0.01 and 0.05 $\mathrm{mM}$ concentrations maintains high fresh weight. Improvement of the fresh and dry weight at low concentrations of $\mathrm{CHI}(0.01$ and $0.05 \mathrm{mM})$ is due to the reduction of respiration (SHAHRI; TAHIR, 2011). GULZAR et al. (2005) and Islam et al. (2011) showed that spraying cut Hemerocallis fulva flowers with 0.01 and $0.05 \mathrm{mM} \mathrm{CHI}$ increased fresh weight more than that of control. Similar finding was observed by Gul et al. (2012) on cut Nerine sarniensis flowers. It seems that CHI suppresses respiration in some species (ISLAM et al., 2011).

It has been shown that ethylene speeds up the decomposition of chlorophyll and early yellowing leaves of many plants (ROBERTS et al., 1989). Results showed that the application of different chemical preservatives delayed the chlorophyll and anthocyanin degradation in comparison to untreated control. Leaf yellowing is characterized by breakdown of chlorophylls, proteins and nucleic acid in the detached leaves. Study of Hatamzadeh et al. (2012) showed that pulse treatment of Alstroemeria cut flowers with 10 $\mu \mathrm{M}$ TDZ delayed leaf yellowing and increased chlorophyll content. Some studies showed that cytokinins are able to retard chlorophyll degradation (FERRANTE et al., 2004). External applications of BA had been effective on retarding senescence of various cut flowers by arresting degradation of protein and chlorophyll (MUTUI et al., 2001; HATAMZADEH et al., 2012). The data on chlorophyll content showed the positive role of $\mathrm{CHI}$, coconut water and BA on preserving the leaves by lowering the percent of weight loss and inhibiting the chlorophyll degradation. Cytokinins have been reported to promote chloroplast development and chlorophyll synthesis (SALLSBURY; ROSS, 1996). Flower's color depends on the amount of carbohydrates in the tissues around the petals. In fact, the carotenoids are pigments that play an important role as antioxidant and are essential compounds for photosynthesis system. These compounds also eliminate reactive oxygen species involving in photosynthetic complexes. Zamani et al. (2011) reported that the use of extended-vase life compounds have a positive effect on maintaining and increasing the amount of pigments in cut chrysanthemum flowers. It has been observed that treatment of flowers with the protein synthesis inhibitor compounds such as CHI prevents cell death by delay the protein degradation (XU et al., 2007; SHAHRI; TAHIR, 2011). The main types of pigments contributing to the flower's color are carotenoids and anthocyanins (AMARJITT, 2000). Ethylene causes petal color fading. Hassanpour; 
Karimi (2010) showed that BA treatment reduced ethylene production in cut Eustoma flowers. BA reduced petal color fading. Petridou et al. (2001) demonstrated that treatment of cut chrysanthemum flowers by BA inhibit anthocyanin formation in the petals, along with its beneficial effect on chlorophyll content.

Absorption of water causes to maintain the cell activity, retaining proteins and ultimately preserving membrane structure. Water balance reduces the activity of MDA, thus delays the senescence of cut flowers. Peroxidation of lipids in cell walls, under the influence of free radicals is the most important mechanism for cell membrane damage and a sign of aging and programmed cell death (GUTE DAHAN et al., 1997). CHI, BA and coconut water decreased MDA content in present work. This compounds also can be helpful in maintaining the membrane. Increasing the antioxidant activity causes delaying aging of flowers (MORTAZAVI, 2011). Activity of antioxidant enzymes inhibits the ethylene biosynthesis and external factors damaging and thus prevents aging cut flowers by neutralizing the toxic effects of free oxygen resulting from the decomposition of hydrogen peroxide that is one of the most important factors in early aging of petals (MORTAZAVI, 2011; MAC ADAM et al., 1992). An increase in the activity of reactive oxygen species such as superoxide radicals and hydrogen peroxide $\left(\mathrm{H}_{2} \mathrm{O}_{2}\right)$ causes aging of flowers through the destruction of proteins, lipids and nucleic acids. To neutralize the toxic effects of reactive oxygen species, a very effective antioxidant system is required that nonenzymatic and enzymatic systems in plant cells are responsible for this role (ASHRAF et al., 1994). SOD is considered a key enzyme in the antioxidant defense system of plants, because it controls the concentration of superoxide anion and $\mathrm{H}_{2} \mathrm{O}_{2}$ in plants (MOZAFFARI; ASSADOLLAHI KOSARRIZI, 2011). Among antioxidant enzymes, POD plays an important role in neutralizing hydrogen peroxide in cells. Therefore, it protects intracellular components such as proteins and fats against oxidation.

\section{CONCLUSIONS}

The coconut water, $\mathrm{BA}$ and $\mathrm{CHI}$ have the potential for extending the vase life of cut $A$. aurantiaca flowers. These compounds improve water relations in stem and causes increasing fresh weight that resulted in prolonging the vase life of cut flowers.

It is possible to extend the vase life of cut alstroemeria flowers using $5 \%$ fresh coconut water. The most levels of coconut water, BA and $\mathrm{CHI}$ improved measured characteristics related to the extending the vase life of cut alsteroemeria flowers in comparison with untreated flowers.

RESUMO: O amarelecimento precoce das folhas em flores de alstroemeria (Alstroemeria aurantiaca) cortadas antes do desenvolvimento floral e da abscisão de pétalas é um importante limitante da qualidade pós-colheita e dos fatores de vida do vaso. A senescência precoce da folha reduz a longevidade pós-colheita das flores cortadas e promove o murchamento da pétala. Um estudo foi realizado para avaliar a resposta de flores de alstroemeria cortadas em diferentes

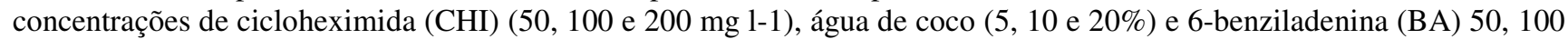
e $200 \mathrm{mg} \mathrm{1-1).} \mathrm{CHI,} \mathrm{água} \mathrm{de} \mathrm{coco} \mathrm{e} \mathrm{BA} \mathrm{prolongou} \mathrm{a} \mathrm{vida} \mathrm{do} \mathrm{vaso} \mathrm{em} \mathrm{todas} \mathrm{as} \mathrm{concentrações} \mathrm{em} \mathrm{comparação} \mathrm{com} \mathrm{o}$ controle, mas a água de coco a 5\% de concentração (com 17,39 dias) foi o tratamento mais eficaz. As flores cortadas de controlo mostraram a menor vida útil do vaso (10,76 dias). A produção de etileno em flores cortadas promoveu a senescência da flor. Todas as concentrações de CHI, água de coco e BA atrasaram a produção de etileno em comparação com o controle. O tratamento de flores cortadas com água de coco a uma concentração de 5\% manteve o maior peso fresco de flores e aumentou o conteúdo de absorção de água. A degradação da clorofila foi significativamente reduzida pela aplicação de CHI, água de coco e BA. O teor máximo de atividade de enzimas antioxidantes e de peroxidação lipídica da membrana (super óxido dismutase e peroxidase) foi obtido em flores cortadas de controle. Assim, 5\% de água de coco fresca tem potencial para ser aplicada como solução de vaso (meio de conservação) devido a prolongamentos das flores de alstroemeria cortadas.

PALAVRAS-CHAVE: Longevidade. Plantas ornamentais. Senescência de pétalas. Reguladores de crescimento de plantas. Vida do vaso. 


\section{REFERENCES}

ADACHI, M.; KAWABATA, S.; SAKIYAMA, R. Effects of temperature and stem length in carbohydrate content in summer grown cut chrysanthemums during development and senescence. Postharvest, Biology and Technology, v. 20, p. 63-70, 2000. https://doi.org/10.1016/S0925-5214(00)00106-X

AGAMPODI, V. A.; JAYAWARDENA, B. M. Effect of coconut water in extending the vase life of anthurium cut flower variety Wild Pink. Tropical Agricultural Research, v. 19, p. 202-209, 2007.

ALVAREZ, M. E. Salicylic acid in the machinery of hypersensitive cell death and disease resistance. Plant Molecular Biology, v. 44, p. 429-442, 2000. https://doi.org/10.1023/A:1026561029533

AMARJIT, B. Plant growth regulators in agriculture and horticulture. Part 5. Food Products Press, v. 5, p. 147-165, 2000.

ASHRAF, M. Y.; AZMI, A. R.; KHAN, A. H.; ALA, S. A. Effect of water stress on total phenols, peroxidase activity and chlorophyll content in wheat. Acta Physiologiae Plantarum, v. 16, n. 3, p. 185-191, 1994.

BECKMAN, K. B.; INGRAM, D. S. The inhibition of the hypersensitive response of potato tuber by cytokinins: similarities between senescence and plant defense mechanisms. Physiological and Molecular Plant Pathology, v. 45, p. 229-246, 1994. https://doi.org/10.1016/S0885-5765(05)80080-3

BURGE, G. K.; BICKNELL, R. A.; DOBSON, B. G. Postharvest treatments to increase water uptake and the vase life of Leptospermum scoparium Forst. New Zealand Journal of Crop and Horticultural Science, v. 24, p. 371-378, 1996. https://doi.org/10.1080/01140671.1996.9513974

ÇELIKEL, F. G.; DODGE, L. L.; REID, M. S. Efficacy of 1-MCP (1-methylcyclopropene) and promalin for extending the postharvest life of oriental lilies (Lilium $\times$ 'Mona Lisa' and 'Stargazer'). Scientia Horticulturae, v. 93, p. 149-155, 2002. https://doi.org/10.1016/S0304-4238(01)00331-4

CHAMANI, E.; IRVING, D. E.; JOYCE, D. C.; ARSHAD, M. Studies with thidiazuron on the vase life of cut rose flowers. Journal of Applied Horticulture, v. 8, p. 42-44, 2006.

CHANASUT, U.; ROGERS, H. J.; LEVERENTTZ, M. K.; GRIFFITHS, G.; THOMAS, B.; WAGSTAFF, C.; STEAD, A. D. Increasing flower longevity in Alstroemeria. Postharvest, Biology and Technology, v. 29, p. 324-332, 2003. https://doi.org/10.1016/S0925-5214(03)00048-6

CHANG, H.; JONES, M. L.; BANOWETZ, G. M.; CLARK, D. G. Overproduction of cytokinins in petunia flowers transformed with PSAG12-IPT delays corolla senescence and decreases sensitivity to ethylene. Plant Physiology, v. 132, p. 2174-2183, 2003. https://doi.org/10.1104/pp.103.023945

DA SILVA, J. A. T. The cut flower: Postharvest considerations. Biology Science, v. 3, p. 406-442, 2003. https://doi.org/10.3923/jbs.2003.406.442

EMONGOR, W. E.; MUTUI, T. M., HUTCHINSON, M. J. Effect of plant growth regulators on postharvest quality and vase life of Alstromeria cut flowers. Tanzania Journal of Agricultural Science, v. 3, p. 21-30, 2000 .

FERRANTE, A.; VERNIERI, P.; SERRA, G.; TOGNONI, F. Changes in Abscisic acid during leaf yellowing of cut stock flowers. Journal of Plant Growth Regulation, v. 43, p. 127-134, 2004.

https://doi.org/10.1023/B:GROW.0000040119.27627.b2

FERRANTE, A.; MENSUALI-SODI, A.; SERRA, G. Effect of thidiazuron and gibberellic acid on leaf yellowing of cut stock flowers. Central European Journal of Biology, v. 4, p. 461-468, 2009.

https://doi.org/10.2478/s11535-009-0039-8 
GUL, F.; TAHIR, I.; RASOOL, I. Senescence and postharvest performance of cut Nerine sarniensis flowers effects of Cycloheximide. International Journal of Botany, v. 8, n. 1, p. 22-30, 2012. https://doi.org/10.3923/ijb.2012.22.30

GUL, F.; TAHIR, I. An effective protocol for improving vase life and postharvest performance of cut Narcissus tazetta flowers. Journal of the Saudi Society of Agricultural Sciences, v. 12, p. 39-46, 2013.

https://doi.org/10.1016/j.jssas.2012.06.001

GULZAR, S.; TAHIR, I.; FAROOQ, S.; SULTAN, S. M. Effect of cytokinins on the senescence and longevity of isolated flowers of daylily (Hemerocallis fulva cv. "Royal Crown") sprayed with cycloheximide. Acta Horticulture, v. 669, p. 395-403, 2005. https://doi.org/10.17660/ActaHortic.2005.669.52

GUTE DAHAN, Y.; YAVIN, Z.; ZILINSKAS, B. A.; HAYYIM, G. Salt and oxidative stress: similar and specific responses and their relation to salt tolerance in citrus. Plant, v. 203, p. 460-469, 1997. https://doi.org/10.1007/s004250050215

HAN, S. S. Benzyladenine and gibberellins improve postharvest quality of cut Asiatic and oriental lilies. HortScience, v. 36, p. 741-745, 2001.

HAN, S. S. Preventing postproduction leaf yellowing in Easter lily. Journal of American Society for Horticultural Science, v. 122, p. 868-872, 1997.

HASSANPOUR ASIL, M.; KARIMI, M. Efficiency of benzyladenine reduced ethylene production and extended vase life of cut Eustoma flowers. Plant Omics Journal, v. 3, n. 6, p. 199-203, 2010.

HATAMZADEH, A., REZVANYPOUR, S.; HASSANPOUR ASIL, M. Postharvest life of alsteroemeria cut flowers is extended by thidiazuron and benzyladenine. South Western Journal of Horticulture, Biology and Environment, v. 3, n. 1, p. 41-53, 2012.

HICHLENTON, P.R. GA 3 and benzylaminopourine delay leaf yellowing in cut Alstroemeria stems. Horticultural Science, v. 26, n. 9, p. 1198-1199, 1991.

HUANG, K. L., CHEN, W. S. BA and sucrose increase vase life of cut Eustoma flowers. HortScience, v. 37 , p. 547-549, 2002.

ICHIMURA, K.; GOTO, R. Extension of vase life of cut narcissus tazetta var. Chinesis flowers by combined treatment with STS and gibberellin. Journal of Japan Society of Horticultural Science, v. 71, p. 226-230, 2002. https://doi.org/10.2503/jjshs.71.226

ICHIMURA, K.; KOHATA, K.; GOTO, R. Soluble carbohydrates in Delphinium and their influence on sepal abscission in cut flowers. Physiology Plant, v. 108, p. 307-313, 2000. https://doi.org/10.1034/j.1399-

3054.2000.108003307.x

ISLAM, S. T.; TAHIR, I.; WASEEN, S.; BHAT, M. A. Effect of cycloheximide on senescence and postharvest performance in Hemerocallis fulva cv. "Royal Crown". Journal of Plant Science, v. 6, n. 11, p. 14-25, 2011.

KIM, J.B. Development of efficient regeneration and transformation system of Alstroemeria.Ph.D. Thesis, Wageningen University, the Netherlands. 160 p. ISBN 90-8504-2801, 2005.

KITTISIRIPAT, W.; TECHAWONGSTEIN, S. Effect of benzyladenine on vase life of gerbera (Gerbera jamesonii) 'Florijn'. Agricultural Science Journal, v. 38, p. 103-106, 2007.

LOUBAUD, M.; VAN DOORN, G. Wound-induced and bacteria-induced xylem blockage roses, Astible, and Viburnum. Postharvest Biology and Technology, v. 32, p. 281-288, 2004.

https://doi.org/10.1016/j.postharvbio.2003.12.004 
MAC ADAM, J. W.; NELSON, C. J.; SHARP, R. E. Peroxidase activity in the leaf elongation zone of tall fescue. Plant Physiology, v. 99, p. 872-854, 1992. https://doi.org/10.1104/pp.99.3.872

MAMARIL, J. C.; TRINIDAD, L. C.; PANER, E. T. Methods of extraction of plant growth hormones in coconut water: I. UV characterization. Trans National Academy of Science and Technology, v. 8, p. 225238, 1986.

MAZUMDAR, B. C.; MAJUMDER, K. Methods on physiochemical analysis of fruits. University College of Agriculture, Calcutta University, p. 136-150, 2003.

MORTAZAVI, S. N. The effect of aluminum sulfate and re-cutting branches on the durability and quality of cut rose cv. Varlon flower. Journal of Plant Production Research, v. 18, n 2, p. 93-105, 2011.

MOZAFFARI, V.; ASSADOLLAHI KOSARRIZI, Z. The effect of manganese and salt in perlite medium on some physiological characteristics of pistachios. The $7^{\text {th }}$ Congress of Iranian Horticultural Science, p. 21802183, 2011.

MUTUI, T. M.; EMONGOR, V. E.; HUTCHINSON, M. J. Effect of accel on the vase life and postharvest quality of alstroemeria (Alstroemeria aurantica L.) cut flowers. African Journal of Science and Technology, v. 2, p. 82-88, 2001.

NAIR, S. A.; SIRASAMY, A.; ATTRI, B. L.; SHARMA, T. V. R. S. Effect of natural and chemical floral preservatives on vase life of cut Gerbera, A comparative study. Indian Coconut Journal, v. 31, n. 3, p. 29-31, 2000.

NOWAK, J.; RUDNICHI, R. M. Postharvest handling and storage of cut flowers, florist greens and potted plants. Timber Press, Portland, Oregon, USA, 1990. https://doi.org/10.1007/978-94-009-0425-5

PAULL, R. E.; CHANTRACHIT, T. Benzyladenine and vase life of tropical ornamentals. Postharvest Biology and Technology, v. 21, p. 303-310, 2001. https://doi.org/10.1016/S0925-5214(00)00153-8

PETRIDOU, M.; VOYIATZI, C.; VOYIATZIS, D. Methanol, ethanol and other compounds retard senescence and improve the vase life and quality of cut chrysanthemum flowers. Postharvest Biology and Technology, v. 23, p. 29-83, 2001. https://doi.org/10.1016/S0925-5214(01)00102-8

ROBERTS, J.; TUCKER, G. A.; MAUNDERS, M. J. Ethylene and foliar senescence. In: Roberts J, Tucher GA (eds.), Ethylene and Plant Development. Butter Worth's, p. 275-287, 1989.

SALLSBURY, F. B.; ROSS, C. W. Plant Physiology. Wad Worth Publication Company Inc. Belmont, California, p. 319-329, 1996.

SANKHLA, N.; MACKEY, W. A.; DAVIS, T. D. Effect of thidiazuron on senescence of flowers in cut inflorescence of Lupinus densiflorus Benth. Acta Horticulturae, v. 669, p. 239-244, 2005 b.

https://doi.org/10.17660/ActaHortic.2005.669.31

SHAHRI, W.; TAHIR, I. Effect of cycloheximide on senescence and postharvest performance of Ranunuculus asiaticus flowers. Pakistan Journal of Botany, v. 42, n. 5, p. 3577-3585, 2010.

https://doi.org/10.1016/j.scienta.2011.03.008

SHAHRI, W.; TAHIR, I. An effective storage protocol for improving the postharvest performance in cut spikes of Consolild ajacis Nieuwl cv. "Violet blue". Scientia Horticulturae, v. 129, p. 154-158, 2011. 
SMITH, A. R.; MOSHKOV, I. E.; NOIKOVA, G. V.; HALL, M. A. The effect of ethylene and cytokinin on GTP binding and MAP kinase activity in Arabidopsis thaliana. p. 77-83. In: 'Biology and Biotechnology of the Plant Hormone Ethylene II'. (Eds. A.K. Kanelis, C. Chang, H. Klee, A.B. Bleecker, J.C. Perch and D.

Grierson.). Kluwer Academic Publishers: Dordrecht, 1999. https://doi.org/10.1007/978-94-011-4453-7_15

SULTAN, M.; FAROOQ, S. Some physiological changes associated with the development and senescence in flowers of daylily (Hemerocallis fulva L.). Plant Physiology and Biochemistry, v. 23, p. 205-208, 1996.

SULTAN, S. M.; TAHIR, I.; ARIF, M.; FAROOQ, S. Cycloheximide spray treatment soon after opening prolongs longevity of detached Morning glory (Ipomoea tricolor) flowers Journal of Plant Biology, v. 29, p. 105-108, 2002.

TOBITA, S. H. S. S.; SHONO, M. Supplemental calcium regulates proline accumulation in NaCl-stressed suspension cultures of Oryza sativa L. at the level of mRNA translation. Pakistan Journal of Biological Science, v. 4, p. 707-710, 2001. https://doi.org/10.3923/pjbs.2001.707.710

VAN DOORN, W. G. Water relations of cut flowers. Horticulture Review, v. 18, p. 1-85, 1997.

VAN DOORN, W. G.; HARMANNUS, H.; SONG, J. S. Water relations and senescence of cut Iris flowers: Effects of cycloheximide. Postharvest Biology and Technology, v. 5, p. 345-351, 1995. https://doi.org/10.1016/0925-5214(94)00034-P

VAN MEETEREN, U.; VAN GELDER, H. Effect of time since harvest and handling condition on rehydration ability of cat chrysanthemum flowers. Postharvest Biology and Technology, v. 16, p. 169-177, 1999. https://doi.org/10.1016/S0925-5214(99)00020-4

WAGSTAFF, C.; LEVERENTS, M. K.; GRIFFITHS, G.; THOMAS, B.; CHANASUT, U.; STEAD, A. D.; ROGERS, H. J. Cysteine protease gene expression and proteolytic activity during senescence of Alstroemeria petals. Journal of Experimental Botany, v. 53, p. 233-240, 2002. https://doi.org/10.1093/jexbot/53.367.233

XU, X.; GOOKIN, T.; JIAG, G.; REID, M. S. Genes associated with opening and senescence of Mirabilis jalapa flowers. Journal of Experimental Botany, v. 58, p. 2193-2201, 2007.

https://doi.org/10.1093/jxb/erm058

ZAMANI, S.; HADAVI, E.; KAZEMI, M.; HEKMATI, J. Effect of some chemical treatments on keeping quality and vase life of chrysanthemum cut flowers. World Applied Sciences Journal, v. 12, n. 11, p. 19621966, 2011.

ZHOU, Y.; WANG, C.; HONG, G. E.; HOEBERICHTS, F. A.; VISSER, P. B. Programmed cell death in relation to petal senescence in ornamental plants. Journal of Integrated Plant Biology, v. 47, p. 641-650, 2005. https://doi.org/10.1111/j.1744-7909.2005.00112.x

ZULIANA, R.; BOYCE, A. N.; NAIR, H.; CHANDRAN, S. Effects of aminooxyacetic acid and sugar on the longevity of pollinated Dendrobium pompadour. Asian Journal of Plant Science, v. 7, p. 654-659, 2008. https://doi.org/10.3923/ajps.2008.654.659 